\title{
Collective Self-Estimate in the Aymaras Communities (Puno-Peru)
}

\author{
Vicente Alanoca Arocutipa, Jorge Apaza Ticona, Roberto A. Quenta \\ Paniagua, Guillermo Cutipa Añamuro
}

Professor of the Faculty of Social Sciences of the National University of the Altiplano National University of the Altiplano of Puno

Received: 10 Nov 2020; Received in revised form: 05 Dec 2020; Accepted: 15 Dec 2020; Available online: 27 Dec 2020 (C2020 The Author(s). Published by Infogain Publication. This is an open access article under the CC BY license (https://creativecommons.org/licenses/by/4.0/).

\begin{abstract}
The study aims to identify collective self-esteem in the communities settled in the Aymara provinces of the Puno region, in that perspective, the objective is to describe the characteristics of collective self-esteem; in the same way to analyze the ways of conceptualizing them and interpret the collective living self-esteem of the populations under study. The methodology that was used was ethnographic and hermeneutical; The work collected perceptions and attitudes related to the type of selfesteem and participation in the communities under study, where in-depth interviews and focus groups were applied in three areas: south, center and north. The results show us that the population of the Aymara communities are aware of their belonging to social identity groups and categories and these are determined and related to the socio-cultural environment, which lead to a positive or negative perception of collective practices and everyday. It is concluded that in the Aymara communities an expression and manifestation of collective self-esteem persists, which has been reconfigured according to socio-cultural changes. The study helps to improve the perceptions and decisions related to the Aymara rural communities in Puno.
\end{abstract}

Keywords-collective self-esteem, identity, perception, attitude, Aymara.

\section{INTRODUCTION}

Today the world lives facing two most shameful events in history, such as the social collapse expressed in corruption and the interest of multinationals and on the other hand the environmental collapse where that biodiversity under the interest of transnational companies is disappearing, we know that the expansion of the world, what we now call globalization, had its first moment in the 15 th century, as a result of the incorporation of America to the destiny of Western Europe (Santiago, 2014), in that scenario, in Latin America, the five centuries of historical oppression have made the original inhabitants of these lands invisible. In our understanding, it is not an involuntary event but rather a decided policy of concealment of a reality that, in the opinion of the rulers, was an obstacle to national construction; hence the option was that of a virtual statistical ethnocide (UNICEF, 2004).

Social changes are as spectacular as technological and economic transformation processes (Castells, 2000), in this perspective, not all systems in the world are the same, although there are general categories that cross the traditional divisions of natural and social sciences (Laszlo, 1997), in short, the states have induced the native peoples prior to their foundation to a process of homogenization and monocultural hegemonization, where the formations of identities and collective self-esteem were built in a fictitious and imposed way.

In the Peruvian case, the work "peruanicemos al Perú" (Mariátegui, 1928) becomes more current, knowing that we have not left the colonial heritage, because, the pending task of the constitution of a Nation-State became the center of concerns of the intellectuals of the bourgeoisie at the end of the century, a concern that has been maintained throughout the 20th century (Cotler, 1992), which has been recreated in the 21 st century, therefore, the problem of the Discrimination, exclusion and racism are problems that these peoples have faced during the colony and are still facing, these categories from the Aymara logic are close to 
“jisk'achasiña” or "jisk'achaña”, they are associated with the humiliating condition of servitude (Rivera, 2010), as a consequence, these situations are determining aspects linked to collective self-esteem in the populations in the Aymara communities of Peru, in our case in Puno.

The present study is structured in three items; In the first instance, it begins with the characterization of collective self-esteem in the Aymara communities; secondly, it addresses the current conceptualization forms of collective self-esteem and thirdly, it develops the hermeneutics of collective self-esteem. We insist that in addressing issues related to indigenous peoples, it is essential to understand the historical process of the peoples of the periphery, who were denied and mutilated during the colony and even in the Republic, since Mesoamerican civilization is a denied civilization, whose presence it is essential to recognize (Bonfil, 2001). However, despite the processes of destructuring and deculturation that, like everyone else, it has suffered, its people and culture are still alive. Neither the constitution of the states nor the republics could end, the Aymara people are a people with no desire to die (Albó, 1988), but they are not alien to the destructuring (Llanque, 1990) and the crisis that the peoples of the periphery face today fragmented into four countries: Bolivia, Chile, Peru and Argentina. The Aymara people are circumscribed in the American confusion, because they created imagined realities: national states, republican institutions, common citizenships, popular sovereignty, national flags and anthems, etc. (Anderson, 1997), suffered a geopolitical fragmentation, the consequences of which are subjects and bills they have been facing (Alanoca, 2017).

The purpose of the research is to make visible and identify the collective self-esteem, still in force among the Aymara communities of the Puno region, despite the accelerated changes that these populations face. It is not about sacralizing or falling into the trap of ethnocentrism, but is about deciphering the experience and validity of those forms of expression that are manifested in various activities, be they social, cultural, economic, environmental and political today, which could very well serve as a support and alternative in these times of social and environmental crisis, which could be inserted in educational policies and in various social programs.

In sum, self-esteem in Aymara communities interweaves principles that guide and delineate the formation and construction of cultural identity and a sense of relevance, however, the dynamics and organizational process structures of Aymara communities have been profoundly disrupted. These are expressed explicitly in the daily life of the inhabitants, especially in the youth and which induces and forces us to develop this research in order to decipher ISSN : 2456-7620 the main cultural values. From this perspective, it is necessary to identify, analyze and interpret collective selfesteem in the Aymara communities in the provinces of Moho, Huancané, El Collao, Chucuito and Yunguyo, in the same way in the districts of Acora, Chucuito and Pichacani, these part of the province of Puno.

\section{MATERIALS AND METHOD}

Due to the nature of the research and according to the objectives set, the work has included three phases. At first, the investigations related and linked to the collective selfesteem of the inhabitants of the Aymara communities have been traced. As part of this process, different libraries have been visited to gather first-source information in addition to the virtual ones that are available today. The second phase was the realization of field work itself, therefore, different localities located in the Aymara provinces of the Puno region have been visited, on the other hand, the cities of Tacna Arequipa, Lima, Ilo in Peru, have been visited. In the same way, the cities of Arica and Iquique (Chile) and La Paz (Bolivia) were visited in order to have a more real vision of the changes that have been occurring in the different communities in relation to the formation of collective self-esteem in the communities Aymara.

Collective self-esteem is subject to changes and the predominance of access to technology and consumer culture, or fashion in the various expressions and collective manifestations, such as anniversary parties, patron saint festivities, marriages and family reunions in Aymara communities from Ilave, Moho, Pilcuyo, Huancané and Candarave. The ethnographic method was used, where we can describe the collective and individual manifestations of the population, to understand the meaning that gives shape and content to social processes and is, therefore, a central method and -the only legitimate one- for social research. (Hammersley, M. and Atkinson, P., 1994). Participant observation techniques, interviews and focus groups have been used, each one with its respective data collection instruments.

\section{RESULTS AND DISCUSSIONS}

Self-esteem as a component of psychology can be approached from its various fields, currently it has to do with the great changes at the level of urban centers, therefore, collective self-esteem is a concept of psychology that refers to how the The self-confidence of the individual interacts with that of other individuals who are part of the same group (Molina, 2017), in that perspective there is a whole story of unforgettable collective pain and suffering, 
that a segment of the population in those cities that they cannot forget, the who were and are victims of suffering, genocide, oppression and violence (Santos, 2015), in this process feelings, self-recognition and redefinition of identities have been interwoven, not only individual, especially collective, which is typical of the Aymara culture, translated into the phrase: 'jiwasaxa mayaktanwa' translates to 'we are one' an expression of these paradigms today is the communities and residents of the cities des, despite the differences they express this expression of collectvism, although it may have a pejorative charge towards those who have still remained in the community.

At present, collective self-esteem is with cultural values, which are those that relate people, things and other beings with respect to a sense and an experiential meaning (Romero V., 2006). In this context, other values are practiced, such as solidarity or 'yanapt'asiña' that has not been lost, although the elements of solidarity have been recreated in relation to the changes of globalization, but they remain a practice. The reciprocity institutions are: Yanapa, Ayni, Chari o ch'artaña, Mink'a, Sataqa, Chiki, Qhatichi, uñaqa, Waqi, Awatiri jaytata, Turki, Kala (Albó, 1988), some are in force, but others already they have been extinguished. Values have a social function is to ensure coexistence and mutual respect, when we think of a community we value a form of grouping or the valuation of life in society. Values are learned in contact with significant people in our life, that is, the person who leaves you deep traces, these can be your parents, teachers, those who teach us love, hope, honesty (Choque, 2017).

Now, the sense of collective self-esteem is approached from three important aspects, which we develop below:

\subsection{Characterization of collective self-esteem in Aymara communities}

First, the characterization of the study area is necessary, in this case the Aymara context in Puno. From this perspective, we consider three important aspects: first, the population of the region; in the sense of ethnic belonging and the presence of peasant communities. The case of visibility or recognition of native or ancestral peoples are recent in Peru. According to the Ministry of Culture (2014), the Aymara constitute one of the 52 indigenous or original peoples of Peru, representing $11 \%$, being the second largest indigenous people in the country. Approximately three-quarters of the population with an Aymara mother tongue lives in the Puno region, this includes the current provinces of Chucuito, Yunguyo, El Collao, Moho, Huancané and part of the province of Puno. The regions such as: Tacna 10\%, Lima and Callao 7\%, Arequipa 4\%, Moquegua 4\%, and among other regions of the south and the coast.

According to the National Institute of Statistics and Informatics (INEI), in the final results of the 2017 National Censuses: XII of Population, VII of Housing and III of Indigenous Communities, the total population of the country amounted to 31 million 237 thousand 385 inhabitants. For the first time, it has been raised about the sense of relevance, of which $60.2 \%$ of the population selfidentified as mestizo. Of which a quarter of the Peruvian population self-identified as an original person (Quechua, Aymara or native of the Amazon), these censuses revealed that $22.3 \%$ of the population aged 12 and over ( 5 million 176 thousand 809) self-identified as Quechua and 2.4\% $(548,292)$ of Aymara origin. Likewise, 79,266 people who said they were native or indigenous to the Amazon were registered; 55,489 Ashaninka people; 37,690 people of Awajún origin; 25 thousand 222 as Shipibo Konibo, and 49 thousand 838 people declared to be from another indigenous or native people. The population of the Puno region, between the national censuses of 2007 and 2017, has decreased by $8 \%$ : now we are 1172,697 , that is, we have decreased by 101,438 inhabitants, this situation can be explained from different points of view, obviously Living conditions are increasingly difficult to face, due to the mismanagement of local and regional government authorities, many of them committed to acts of corruption.

Table 1: Rural and urban population at the departmental level in Puno according to province-2017.

\begin{tabular}{lccccc}
\multicolumn{1}{r}{ Province } & \multicolumn{2}{c}{ Rural Population } & \multicolumn{2}{c}{ Urbana population } & \\
\cline { 2 - 5 } & Quantity & Percentage & Quantity & Percentage & Total \\
\hline Puno & 80582 & 14.8 & 139912 & 22.0 & 219494 \\
Azángaro & 76823 & 14.2 & 33569 & 5.3 & 110392 \\
Carabaya & 40416 & 7.5 & 32936 & 5.2 & 73322 \\
Chucuito & 68841 & 12.0 & 24161 & 3.8 & 89002 \\
El Collao & 42040 & 7.8 & 21831 & 3.5 & 63878
\end{tabular}


Nov-Dec 2020 / Available online: https://ijels.com/

\begin{tabular}{lccccc} 
Huancané & 49937 & 9.2 & 7714 & 1.5 & 57651 \\
Lampa & 27624 & 5.1 & 13232 & 2.1 & 40856 \\
Melgar & 30713 & 5.7 & 36425 & 5.8 & 67138 \\
Moho & 16496 & 3.0 & 3257 & 0.5 & 19753 \\
San Antonio Putina & 11780 & 2.2 & 24333 & 3.9 & 36113 \\
San Roman & 28885 & 5.3 & 278532 & 44.2 & 307417 \\
Sandia & 46739 & 8.6 & 4003 & 0.6 & 50742 \\
Yunguyo & 25173 & 4.6 & 11766 & 1.9 & 36939 \\
\hline
\end{tabular}

Source: INEI 2017.

According to the data provided by INEI 2017; In the first place, the province of Puno has $14.8 \%$ of rural population, followed by Azángaro 14.2\%, Chucuito 12.0\%, El Collao $7.8 \%$, Carabaya $7.8 \%$, Sandia $8.6 \%$ and in last place is San Antonio de Putina with 2.2. \%. So, the rural population continues to be more important; in the Quechua zone
Azángaro is the one with the highest percentage of Quechua population and in the southern province of Chucuito the rural Aymara population stands out. For our case, the provinces of Moho and Huancané have been considered.

Tabla 1:Población por pertinencia lingüística y étnica de Puno según provincia-2017.

\begin{tabular}{lccc}
\hline \multicolumn{1}{c}{ Province } & Aymara & Quechua & Others \\
\hline Puno & 71019 & 81995 & 66480 \\
Azángaro & 402 & 82961 & 27029 \\
Carabaya & 510 & 52770 & 20042 \\
Chucuito & 69588 & 845 & 18569 \\
El Collao & 49726 & 719 & 13430 \\
Huancané & 29439 & 17030 & 11182 \\
Lampa & 304 & 30659 & 9893 \\
Melgar & 246 & 48323 & 18569 \\
Moho & 15987 & 187 & 3579 \\
San Antonio Putina & 4124 & 21785 & 10204 \\
San Roman & 42603 & 168940 & 95874 \\
Sandia & 6061 & 31411 & 13270 \\
Yunguyo & 28351 & 347 & 8241 \\
\hline
\end{tabular}

Source: INEI 2017.

The Puno region is characterized by the presence of three indigenous peoples such as the Quechuas, Aymara and the Uros, these according to the database of the Ministry of Culture. The northern provinces such as: San Román, San Antonio de Putina, Puno and Melgar are more urban and ISSN: 2456-7620 mostly Quechua, on the other hand, Lampa, Azángaro, Carabaya and Sandia, are more rural and Quechua; on the other hand, Chucuito, el Collao, Yunguyo, Moho and Huacané are mostly rural and Aymara. The Uros, constitute an original town located in the bay of Puno, 
whose majority population has settled for centuries in huge reed rafts called "floating islands", which sail on the waters of Lake Titicaca; and whose language belongs to the Uru-Chipaya linguistic family (Ministry of Culture, 2019).
Although these data may be loaded with certain elements of mistrust, due to the constant mobility of the population, but they are official and reflect a real expression of the characteristics of the population in relation to cultural and linguistic belonging.

Table 3: Peasant Communities in the department of Puno according to province-2016.

\begin{tabular}{|c|c|c|c|c|}
\hline Province & $\begin{array}{c}\text { Total de } \\
\text { Communities }\end{array}$ & $\begin{array}{l}\text { Recognized } \\
\text { and titled }\end{array}$ & $\begin{array}{l}\text { Recognized by } \\
\text { holder }\end{array}$ & $\begin{array}{c}\text { Titled Extension } \\
\text { (ha) }\end{array}$ \\
\hline Azángaro & 284 & 230 & 54 & 172170,92 \\
\hline Carabaya & 51 & 46 & 5 & 490102,68 \\
\hline Chucuito & 146 & 125 & 21 & 292155,00 \\
\hline El Collao & 133 & 123 & 10 & 176098,38 \\
\hline Huancané & 126 & 111 & 15 & 140839,77 \\
\hline Lampa & 96 & 67 & 29 & 177849,24 \\
\hline Melgar & 78 & 66 & 12 & 88233,24 \\
\hline Moho & 25 & 21 & 4 & 27370,40 \\
\hline Puno & 213 & 168 & 45 & 232862,80 \\
\hline San Antonio Putina & 52 & 26 & 26 & 73769,51 \\
\hline San Roman & 38 & 25 & 13 & 44044,47 \\
\hline Sandia & 40 & 29 & 11 & 225166,78 \\
\hline Yunguyo & 21 & 20 & 1 & 21649,84 \\
\hline TOTAL & 1303 & 1057 & 246 & 2162313,04 \\
\hline
\end{tabular}

Source: Directorio 2016, Comunidades Campesinas del Perú, IBC-Cepes.

From the table it can be inferred that in Puno there are a total of 1303 Peasant Communities, distributed in the thirteen provinces of the Puno region; the province of Azángaro is the account with the largest number of communities with 284; then Puno follows with 213; followed by Chucuito with 146; El Collao with 133 communities and so on respectively. In these communities, the lieutenant governors fulfill the function according to ancestral traditions and customs, obviously it varies not only by province, but even by community.

We insist that the population by provinces, the sense of belonging and the presence of communities are important aspects that make up collective self-esteem, it is obviously related to other aspects, such as economic, social, cultural and political. The discipline of psychology considers selfesteem as the evaluative perception of oneself, referred to strictly individual and personal issues; centered on the ego, however for the present study we consider collective self- esteem as the collective perception of the inhabitants of the communities settled on the Peruvian side, in fact it begins with the fragmentation of the Aymara culture, or the imagined communities (Anderson, 1997 ), for example, the creations of the provinces of Moho, San Antonio de Putina are later, although they are aspirations of the population, but more have been responses to the centralism and discrimination of the regional colonial backwardness, such as the creation of the provinces of Yunguyo and El Collao in the south.

In this perspective, many psychosocial theories of selfesteem have highlighted the personal or more individualistic aspects of self-concept. From this point of view, people are seen as striving to maintain, protect and reinforce a positive image of themselves. Thus, it appears that people with high personal self-esteem tend to be influenced by self-enhancement bias (unrealistic positive thoughts, illusion of control, and unrealistic optimism 
about the future) (Sanchez, 1999). We know that the territory, or the Aymara nation, was not only fragmented, but relegated by the states, unlike Bolivia, where it has become a cohesive force due to its geographical, social and demographic dimension, however, historical links persist, social, political, economic, cultural, especially linguistic (Alanoca, Mamani, \& Condori, 2019), despite the fragmentation and changes to which they were subjected, even cultural values in the Aymara context interweave principles that guide and delineate The formation and construction of personality, however, have been profoundly disrupted the dynamics and organizational process structures of the Aymara communities, which are explicitly expressed in the daily life of the settlers, especially in the youth and the which induces and forces us to develop this research in order to decipher the main cultural values (Alanoca, Apaza, Quenta, \& Cutipa, 2019), which you has a relationship with collective self-esteem.

It is no longer possible to think about or identify static communities, because the crisis of the civilizational model facing the current world, to which indigenous peoples are not alien, has its origin in the great events experienced, as Hobsbwam illustrates, humanity survived, but the great edifice of nineteenth-century civilization collapsed in the flames of war as the pillars that supported it collapsed (Hobsbawm, 1999).

Environmental awareness has permeated the institutions of society and its values have gained political appeal at the price of being falsified and manipulated in the daily practice of large companies and bureaucracies (Castells, 2000). Political systems are mired in a structural crisis of legitimacy, sunk periodically by scandals, essentially dependent on the support of the media and personalized leadership, and increasingly isolated from the citizenry (Castells, 2000), in short, Collective self-esteem is complex in its approach, but with certain particularities in force among the Aymara communities of the Puno region.

\subsection{Forms of current conceptualization of collective self-esteem}

There are various forms of conceptualization of collective self-esteem, from the intra logic it is subject to the sense of relevance and self-recognition, which from the language logic corresponds to answer the question: Khitinakapxtansa? From Spanish it would be Who are we? This question was developed in a study with the students of the Andean Linguistics and Education master's degree (Montoya \& Lopéz, 1988),

A common characteristic of the different instruments for measuring personal self-esteem is their individualistic character, centered on the individual's self-evaluations of their personal attributes, both in the private sphere (values, goals, ideas, emotions, etc.) and in the interpersonal (attractiveness, reputation or popularity). However, the self-concept also includes aspects of a social or collective nature, that is, those that derive from belonging to groups or social categories (gender, race, religion, occupation, etc.). Thus, while our social identity refers to the way in which people consider the social groups to which they belong, collective self-esteem refers to the evaluation made by the individual himself and the perception of the evaluation that others make about those groups (Sanchez, 1999).

The Aymara populations of Huancané, Moho, El Collao, Chucuito, Yunguyo, as well as the populations of Acora, Chucuito and Pichacani in the province of Puno, express and manifest their self-recognition in communal festivals, meetings, tasks, where the validity is generally shown reciprocity in a communal context. According to Hinkle and Brown, collective self-esteem would be more related to collectivist values on the assumption that group identification would reinforce the values that guide the belonging of individuals to endogroups (Hinkle, 1992). For the Aymara, moral values are those that respond to actions as correct or incorrect that lead the "jaqi" (human) to defend and grow in their dignity, the person that leads to the moral good that improves and completes, the moral value that it perfects man in his will, his freedom and his reason, and it can also be well accepted. In this regard, one of our informants states:

When in the community one of the members does not respect the others, in many times it is sanctioned by a local authority, because the authority is the father of the community who has an accepted behavior, the punishment is authorized with the use of the whip, the punishment for us is to correct the behaviors of the members of the community, that is, through the whip the positive and corrective energies are transmitted, to heal the bad morals and the incorrect attitudes in the family and in the community (Informant No. 1).

From a psychological approach, identity is understood as a subjective conceptualization about oneself, which is constructed from the interaction of different cognitive, affective and social processes, inserted in cultural settings and specific local contexts (Tajfel, 1982). Self-esteem as 
well as collective self-esteem (AEC) are important to survive as a personal identity and also in the group. The transition from the age of adolescence to adulthood is a crucial stage in the life of any individual. During this phase the individual faces many problems and it is often very difficult to maintain the optimal level of personal self-esteem (AEP) and AEC (Sharma, 2015). People evaluate themselves on the basis of daily successes and failures, in social comparisons with others and in comparisons with their own internal parameters, as well as with the evaluation made by the individual himself and with the perception of the evaluation that they make Others about these groups: this is how the personal (AEP) and collective (AEC) character of self-esteem is presented. (Ramos, 2016). In this regard, we have testimony from one of our informants:

We change every moment, when we are girls we think differently and I think that in any conversation we imagine a lot and they tell us she is talking because she is wawa and she still does not realize what she says. So every day and as we grow we are different and we realize by ourselves the facts and the things we do. Of course we do not know self-esteem by name, rather we know how to say we have to look at others, that for me is to walk in a family context without problems, of course it exists but let it not be visible in a communal context, when one is like that we receive respect and they ask us to advise young people, so every moment of our life we become aware of life (Informant No. 2).

The notion of Wawa in the Aymara context is seen as the construction of the natural being to the social being and within it, the path that community members travel from birth, through life, in their relationship with death, their personal limits, that lead them to transcend the community and spiritual limits of their ancestors, in this regard an informant from the town of Acora tells us:

For us, wawa is a word that we can assign to boys and girls, but also to adolescents and adults, in some cases when they are already married, their parents continue to say mi wawa. So the word wawa does not cut the ages of a person. Well, we also say wawa to small animals and plants, because they need care (Informant No. 3).

For the Aymara, having a child is not a problem, nor is it poverty. Having a child is a great blessing from God, from the divinities of mother Pachamama. Having a child is having happiness, joy, warmth, abundance, etc. In the home. In the upbringing of the first child, sacrifice is shown and later between siblings and they are growing up. In this regard, one of our informants tells us:

"... Having wawa is very nice, it is feeling complete, where you learn to have patience, tolerance, affection, kindness, to love and be loved by the wawas, with his tender and smiling gaze he steals our hearts, that's why my husband He says; Having a child is a great happiness, it is feeling like a garden full of flowers..."(Informant No. 4).

Another of our informants tells us:

"... When a woman is pregnant, she must continue to do the farm in that way she exercises her body, otherwise the wawa will develop in one place, when the mother exercises the baby also exercises. People have recommended to me that I should not be sitting in one place, rather I should be walking in the farm, nor does that mean making a lot of effort, always all activities with care"(Informant No. 5).

One of our informants tells us, tells us:

For the alpaquero the birth of a child is welcome because the baby that is being born will enforce the rights of the family, it is also needed for herding cattle and by custom it is said: when a little boy is born this child will defend his father in trouble, land disputes and others. When she is a little woman she is considered as the arrival of bonanza, she will be together with her parents until she is young, she will give warmth at home (Informant No. 6).

The child, as another member of the family with his tender age, is the one who recreates affection, harmony, health and balance in the family, he or the children are the ones who recreate the different activities of family, community, etc. He likewise helps in the different activities carried out by parents; Whether in agricultural work, grazing and other household chores, parents as adults are always teaching their children to be consciously and unconsciously in the same way, the attitudes and reflections of children towards parents motivate them to learn new experiences.

It is necessary to examine the Aymara concepts of childhood in the context of the communities, for this reason it is also necessary to examine the role of the Wawa in the mediation of Andean ideas about identity and difference, the same and the other, as a vital part of Andean interculturality. According to the criteria of multiculturalism, more attention is paid to the socialization 
of the wawa through social interventions in the development and maturity of its corporality, than to its intellectual life (Yapita, 2000). The socialization of the wawas is carried out through the "Thakhi" (way) of the wawa, through which he (she) will become a social person who works for the community. For this reason, since the community is born, it is an important part of the journey it takes. Thus he (she) learns to respect the authorities, her parents, close relatives and also spiritual ones. But he, too, will always learn from the example of his predecessors. The learning that the child carries out in the community is carried out through formal paths institutionalized in authorities, rituals, customs, practices, teaching of their elders, play, etc. In this regard, there is testimony from our informant:

Wawas are always beautiful and are essential in our lives, at the sowing season our relatives look for us so that we can do the sowing, it is because we have wawas, it is so that the production of crops is abundant. Wawas are not born knowing everything but they learn with us, so when we are doing our activities they also want to do it, so their father knows how to make miniature tools for them to play (Informant No. 7).

The notion of "jaqi" (person) in Aymara culture is considered to be the male or female personality. The construction of the personality of the Aymara man is developed in the process of work activity, typical of the Aymara communities, and each town is distinguished by the type of llijla for the wawa loaded. Although these have changed considerably. In childhood, observing in the first instance on the back of his mother and replicating through symbolic play the tasks of the parents and attending to their educational orientations. Later in the older ages, assuming the tasks entrusted by the parents. All this sharing with the educational action of the school and the college, whose content is not related to the Aymara culture, nor with the concrete work and aspirations of the Aymara of the communities of the provinces of Huancané, Moho, El Collao. Chucuito, Yunguyo and the districts of Acora, Chucuito and Pichacani, generating conflicts not only cognitive, but also of a moral and cultural identity.

Aymara communities are structured on the basis of the complementary opposition dialectic, that is to say, that the "whole is divided into two opposite but complementary halves" (Montes, 2000). We can then point out this logic is expressed in the following aspects: the space is divided into high-low, that of the population by male-female sexual opposition, that of the bilaterality of kinship in maternal-paternal, that of the bilaterality of the human body as right-left. Although these relationships are ISSN: 2456-7620 asymmetrical, they are also complementary because each one has what the other lacks, so that they complement each other in a single vital sense. Here the role of reciprocity is fundamental, since this social mechanism is in charge of establishing harmonious relationships between the parties. The case of Huancané is a form of collective identification on which Urinsaya and Janansaya, or Jila Sullca; or chiqa kupi, in the case of Ilave this question has been recreated, in Yunguyo and Chucuito, but the collective notion prevails, but with some changes. In this regard, we have testimony from one of our informants:

In our community we are all as a couple is to help each other in life, when I am sick my husband cooks, so not only the kitchen activity is for women, another, my husband used to weave ponchos in flat weave and also looms, in the community does not have a specific task for men and women (Informant No. 8).

In sum, one of the forms of conceptualization of collective self-esteem in the Aymara communities of Puno today persists in self-identification and recognition as: "Aymaranakpxtanawa", which translates to 'we are Aymara'. This form of conceptualization is closely linked to " jiwasaxa jaqinakapxatanwa which translates as: 'we are human beings' these questions have been verified and collected in the different cities of southern Peru where the inhabitants of the Aymara communities have migrated, we have been in the different patron saint or anniversary festivals where there is always some group or collective of residents who participate in the festivities, although pride or vanity often prevails, which is the product of the consumer culture process, which has been established by "Homo videns" (Sartori, 1998), or the "homo brutus", on the other hand, there are unresolved dilemmas of multiculturalism and hybridization in Latin America (García, 1990), but there are and the "sapha" which is the root of expression of collective self-esteem, but increasingly upset that is breaking unity or mayaktanwa or "we are one".

\subsection{The hermeneutics of collective self-esteem in Aymara communities}

The interpretation of collective self-esteem for the inhabitants of the Aymara communities is subject to the kinship relationships that each family group has in other urban spaces, such as in Tacna, Arequipa, Moquegua and Cusco, as capitals of the regions, or in Lima, their relatives, in their various degrees, are linked to the community, especially in the patron saint festivals, which take place in each locality, be it urban or rural. Therefore, it is important to consider that modern man seems to 
believe that they must be learned, that becoming a literate person is arts that must be learned, that becoming a competent architect, engineer or worker requires much study. . But living is so simple that learning does not require any particular effort. Precisely because each one "lives" in some way of life, it is considered as a matter in which everyone passes for an expert. But it is not due to the fact of having mastered the art of living to such a degree that man has lost the sense of its difficulty (Fromm, 2003).

The testimonies of Aymara migrants such as the case of Unicachi in Lima, who many arrived as helpers or laborers, and thanks to the collective effort and the principle of reciprocity today have become prosperous traders, not only in Lima, but Aymara in Arequipa, Tacna, Juliaca, Puno, for example our informants told us:

I arrived in Puno, as a tricyclist, then I bought a motorcycle, now I have a taxi, but my countrymen have always helped me, many times we meet at the party, both in Puno and my land, which is Juli. Now my children are professionals, one is an architect (Informant No. 10).

The aspiration and hope to face not only individually, but collectively, this is a situation that stands out in the testimonies of our informants. Self-stereotypic components influence collective self-esteem. Specifically, the positive components increase it and the negative components mitigate it. In a second moment, collective self-esteem would influence the degree of identification, and this in turn would directly influence social well-being, which would positively affect the psychological and subjective expressions of well-being (Espinosa, Freire, \& Ferrán, 2016). For example, the Yunguyo festivities on October 10; on December 8 at Juli; on September 29 in Ilave; the feast of the crosses in May in Huancané, or on October 6 in Pomata; In Chucuito, among Aymara localities, it is a clear union of identity and sense of expression and collective relevance, but in many cases the consumption of beer prevails, which is a particularity of the Aymara world.

The history of Peru, or the social sciences itself, is difficult to address, it is more circumscribed within the framework of the monocultural and hegemonic "official" history of the "intellectuals" and "academics" of the academy, very manipulated, it is built under the chronicles and colonial information, with exclusive and discriminatory racist tendencies towards native peoples (Alanoca, 2016). From the social sciences, in the line of complex thought and critical theory, it allows us to make visible and show, error, ignorance, blindness, progress everywhere, at the same time as our knowledge. Therefore, a radical awareness is necessary (Morin, 2001), under this perspective the crisis of the social sciences was debated (Husserl, 2008). In this perspective, collective self-esteem, for the communities is interpreted in their contemporaneity, it is a psychosocial product immersed in a culture of thousands of years of construction, whose fundamental material and immaterial elements are present in the XXI century of which it is not deepened in the study of its content that today has full effect in the daily life of the large Aymara population of the Puno region - Peru.

The most existing information is focused on the material aspect and very neglected, invisible in its psychological and psychosocial part, hated, stigmatized and on the verge of being destroyed by ideology and hegemonic Western thought from the presence of Europe to the point of qualifying it as paranoia Aymara (Olmedo, 2006) for their resistance for nearly 500 years with a fundamentally ungracious culture. The analysis of the Aymara personality framed in a psychosocial vision allows us an interdisciplinary approach, particularly in the field of social sciences, this will allow a comprehensive conception of it, fundamentally highlighting a cultural vision. The category personality with different names in its translation is a universal concept in the social sciences, but the society and culture where it is developed assumes a particularity.Collective self-esteem as a particularity, consequence of its dynamic construction within the Aymara culture, after centuries of the process of destruction of native cultures by the dominant European culture, is it possible to speak of self-concept, self-esteem, both individual and collective of the Aymara communities, in their version, for example, of positive or healthy selfesteem? The answer is positive when the concept of the hard core of pre-Hispanic cultures proposed by (López, 2001) is assumed, according to the author, it is defined as "An articulated complex of cultural elements, highly resistant to change", which allow to give a unique structure traditional heritage and allow new cultural elements to be incorporated into said structure, giving coherence to the cultural context. One of those central elements of the cultural complex resistant to change is ideology, and, in the Andean world, Aymara is its religion centered around the Pachamama, and that, in the process of production in daily social relations, have generated thoughts, norms, institutions and customs.

This situation is currently adverse, the crisis of the civilizational model facing the current world, to which the indigenous peoples are not alien, has its origin in the great events experienced, as Hobsbwam illustrates, humanity survived, but the great edifice The nineteenth-century civilization collapsed amid the flames of war as the pillars 
that supported it collapsed (Hobsbawm, 1999), above it, political systems are mired in a structural crisis of legitimacy, periodically sunk by scandals, essentially dependent on the support from the media and personalized leadership, and increasingly isolated from the public (Castells, 2000).

Collective self-esteem from an emancipatory perspective is to make visible, it is very important to know the other story, the respect and dignity that indigenous peoples demand; it is new for those who never considered them as human beings but simply as figures in a labor market or simple pack animals (Montoya, 2016). The "conception of the world" is determined by the situation of politicalcommercial and political-social interests. But all this occurs at a time when modern capitalism has already triumphed, emancipating itself from its old footholds. Just as it could only break the old forms of the medieval economic constitution by relying on the incipient power of the modern state, the same could happen (we will say provisionally) in its relations with religious powers (Weber, 1984).

In Latin America at least the processes demonstrate the opposite: it is from technology, from its logo-technology, that one of the most powerful and profound impulses towards the homogenization of life comes from. One of the "novelties" that modern communication technologies would present would be the contemporaneity between the time of their production in rich countries and the time of their consumption in poor countries (Barbero, 1991). The generation of young people has become disconnected with the historical reality of the peoples who have lived in pain and systematic discrimination. People who so naively allow themselves to be carried away by their own naivety and political immaturity, on the one hand already feel like political subjects, who would be responsible for determining a destiny and organizing society in freedom. But on the other hand, they stumble upon the fact that certain iron limits are imposed on such endeavor by circumstances (Adorno, 1970).

The existence of classes, each one knows from experience, is a conjuncture of struggles. And that fact undoubtedly constitutes the greatest obstacle for a scientific knowledge of the social world and for the resolution (because there is one ...) of the problem of social classes (Bourdieu, 1998), in recent years there has been a resurgence of peoples ancestral in the world and the specific case of the Aymara in Latin America, but it is known that both capitalism and communism have an anthropocentric approach (although one individualist and the other collectivist), both consider the human being as the king of creation and the other forms of existence become objects that can be used, used ISSN : $2456-7620$ and abused (Huanacuni, 2010). These changes have to do with the fact that time and space shape our perception of reality, with changes in technology, society is already controlled by an elite not contained by traditional values. What gives cohesion to this elite is not any family, race, or religion: it is the perpetuation of their oligarchy through technological and scientific tools (Brzezinski, 1979), despite this, we continue to face the crisis at all levels.

In short, a kind of de-traditionalization of the Aymara communities has been generated, in their forms of organization, formerly ranches, communities, now populated centers, to which the educational system was par excellence a key element of colonization not only through school, but also through the school and university, which have been following the standardization and homogenization model to build a national identity, feigned and imagined, without counting on the collective subjects and actors. Because, in the context of the Aymara, the educational system is substantial and facilitates changes in the consumption of food by the inhabitants in the communities, in recent years the habits of daily life have been disrupted in different aspects (Apaza, Alanoca, Ticona, Calderon, \& Yuselino, 2019), to these forms are added the Colonization process through social programs and the means of social communication and TICs.

\section{CONCLUSION}

At present, among the Aymara communities of the Puno region, it is contextualized from three aspects, a first due to the characterization of the population, the sense of ethnic belonging and the presence of the peasant communities; In the process they have been resisting against the ethnocide and genocide to which they were subjected, it was fragmented during the foundations of the states, without their consent, independence was only a change of owners in the heat of the struggle of the Aymara themselves.

In this context there are own forms of conceptualization of collective self-esteem, which are expressed in the sense of cultural relevance, expressed which intertwine with the practices of cultural values, despite overwhelming globalization via technology, they still persist in everyday life, which they are anchored in the activities of agriculture and livestock.

In the Aymara communities of the Puno region, there are own forms of interpretation of collective self-esteem, which are expressed above all in the patron saint festivals, which are linked to the practices of cultural values, which have not only communal significance, but also go beyond the geographic context, that is, it is not only rural, but urban. On the other hand, the detraditionalization of the 
Aymara communities is more current, which must be taken into account, to avoid the process of extinction of the communities that are still moral reserves of the protection of life and respect for dignity human.

\section{ACKNOWLEDGMENT}

Our gratitude to the Aymara communities of the Huancané, Moho, El Collao, Chucuito, Yunguyo provinces, and to the Acora and Chucuito districts and to all the informants who provided us with information and related from their daily experiences about self-esteem in the Aymara communities. To the National University of the Altiplano for the financing, because it allowed us the opportunity to carry out a collective and interdisciplinary work.

\section{REFERENCES}

[1]Adorno, T. (1970). Educación para la emancipación. Madrid: Morata.

[2]Alanoca , V., Mamani, O., \& Condori, W. (2019). El signifcado de la educación para la nación aymara. Revista Historia de la Educación Latinoamericana, 21(32), 227-246. doi:htps://doi.org/10.19053/01227238.6994

[3]Alanoca, V. (2016). El desarrollo del pensamiento crítico en el Altiplano de Puno. Comuniacción, 60-68. Recuperado el 11 de diciembre de 2017, de http://www.comunicacionunap.com/index.php/rev/article/vie $\mathrm{w} / 111$

[4]Alanoca, V. (2017). Los aymaras de Ilave (Perú). Su configuración como nuevos actores y sujetos históricos en la larga lucha de emancipación indígena. Sevilla: Universidad Pablo de Olavide. Tesis de Doctorado .

[5]Alanoca, V., Apaza, J., Quenta, R., \& Cutipa, G. (2019). Los valores de la cultura aymara en la construcción de la personalidad. Revista de Investigaciones de la Escuela de Posgrado, 8(1), 884-894. doi:http://dx.doi.org/10.26788/riepg.2019.1.110

[6]Albó, X. (1988). Raices de América: El mundo Aymara. Madrid: Unesco.

[7]Anderson, B. (1997). Comunidades imaginadas. México: Fondo de Cultura Económica.

[8]Apaza , J., Alanoca, V., Ticona, C., Calderon, A., \& Yuselino, M. (2019). Educación y alimentación en las comunidades aymaras de Puno.Comuni@ccion: Revista de Investigación en Comunicación y Desarrollo, 10(1), 36-46. doi:http://dx.doi.org/https://doi.org/10.33595/22261478.10.1.328

[9]Barbero, J.-M. (1991). De los medios a las mediaciones. México: Gustavo Gili S.A.

[10]Bertonio, L. (2004[1612]). Vocabulario de la lengua aymara. Arequipa: Ediciones El lector.

[10]Bonfil, G. (2001). México profundo. Una civilización negada. México: Conaculta.
[11]Bourdieu, P. (1998). Capital cultural, escuela y espacio social. Madrid: Siglo XXI.

[12]Bowlby, J. (2006). Vínculos afectivos: Formación, desarrollo y pérdida. Madrid: Morata.

[13]Brzezinski, Z. (1979). La era tecnotrónica. Buenos Aires: Paídos.

[14]Cantón, J., \& Cortés, M. (2003). El apego del niño a sus cuidadores. Madrid: Alianza.

[15]Casado, L., \& Prat, T. (2010). Resolución de conflictos. Lima: Punto y coma.

[16]Castells, M. (2000). La socieadad de la red. Madrid: Alianza.

[17]Choque, A. (2017). Los valores y espiritualidad andina en la cultura aymara. Universidad Mayor de San Andres, La Paz . Recuperado el 09 de diciembre de 2017, de https://www.academia.edu/28731620/LOS_VALORES_Y_E SPIRITUALIDAD_ANDINA_EN_LA_CULTURA_AYMA RA_Bolivia: http://formacionintegral.com.ar/website/?p=2725

[18]Cotler, J. (1992). Clases, estados y nación en el Perú. Lima: Instituto de Estudios Peruanos.

[19]Cultura, M. d. (2014). Aimaras comunidades rurales en Puno. Lima: Ministerio de Cultura.

[20]Elkonin, D. B. (1980). Psicología del Juego. Madrid: Pablo del Río.

[21]Fromm, E. (2003). Ética y psicoanálisis. México: Fondo de Cultura Económica.

[22]Hammersley, M. y Atkinson, P. (1994). Etnografía. Barcelona: Paidós.

[23]Henríquez, N. (2014). Conflicto social en los andes. Lima: Pontificia Universidad Católica del Perú.

[24]Hinkle, S. B. (1992). procesos en la teoria de la identidad social. Psicología social, 211-240.

[25]Hobsbawm, E. (1999). La historia del siglo XX . Buenos Aires : Crítica Grijalbo .

[26]Huanacuni, F. (2010). Vivir bien/buen vivir. La Paz: Coordinadora Andina de Organizaciones Indígenas CAOI.

[26]Husserl, E. (2008). La crisis de las ciencias europeas y la fenomenología trascedental. Buenos Aires: Prometeo.

[27]Laszlo, E. (1997). La gran bifurcación. Barcelona: Gedisa.

[28]Llanque, D. (1990). La cultura Aymara: desestructuración o afirmación de identidad. Lima: Tarea.

[29]Mariátegui, J. C. (1928). Peruanicemos al Perú. Lima: Amauta.

[30]Ministerio de Cultura. (03 de Octubre de 2019). https://bdpi.cultura.gob.pe/pueblos/uro. Obtenido de https://bdpi.cultura.gob.pe/pueblos/uro

[31]Molina, M. (02 de Agosto de 2017). Barcelona y la autoestima colectiva. La vanguardia. Recuperado el 30 de junio de 2019, de https://www.lavanguardia.com/opinion/20170802/432734900 25/barcelona-y-la-autoestima-colectiva.html

[32]Montes, F. (2000). La mascara de la pierdra. La Paz Bolivia: Quipus.

[33]Montoya, R. (1980). Capitalismo y no capitalismo en el Perú. Lima: Mosca Azúl editores.

[34]Montoya, R. (2016). Visiones del Perú en la antropología peruana(1941-2015). Investigaciones sociales, 20(37), 7-16. 
Recuperado el 31 de diciembre de 2017, de http://revistasinvestigacion.unmsm.edu.pe/index.php/sociales /article/view/13423/12043

[35]Montoya, R., \& Lopéz, L. E. (1988). ¿Quiénes somos?: el tema de la identidad en el altiplano. Lima: Mosca Azúl.

[36]Morin, E. (2001). Introducción al pensamiento complejo. Barcelona: Gedisa.

[37]Ochoa, V. (1974a). El proceso de la formación del hombre aymara (Primera parte - de niño a joven). Boletín Ocasional $N^{o} 15$, Chucuito-Perú, Noviembre., 5-9.

[38]Papalia, E., Wendko, O. S., \& Duskin., R. (2009). Papalia E., Dianne; Sterns, Harvey L; Feldman, Ruth Duskin y CamposPsicología del desarrollo de la infancia a la adolescencia. México: McGrawHill Interamericana.

[39]Quenta, R. (2013). La consctrucción de la personalidad e identidad aymara en niños preescolares en las comunidades del distrito de Pilcuyo El Collao Puno 2011. Universidad Nacional San Agustín. Arequipa: Universidad Nacional San Agustín.

[40]Ramos, D. (2016). Autoestima personal y colectiva: asociación. Anuario de psicología, 75-82.

[41]Rivera, S. (2010). Ch'ixinakax utxiwa. Buenos Aires: Tinta Limon.

[42]Romero , V. (2006). El significado socio- comunitario y ecológico de los valores aymaras. Punto cero, 11(12), 59-68. Recuperado el 09 de diciembre de 2017, de http://www.scielo.org.bo/pdf/rpc/v11n12/v11n12a06.pdf

[43]Romero, R. (1994). Ch'iki. La Paz: Instituto de Investigaciones de la Facultad de humanidades y Ciencias de la Educación de la Universidad Mayor de San Simón.

[44]Sanchez, E. (1999). Relación entre la autoestima personal, la autoestima colectiva y la participación en la comnunidad. Anales de psicología, 252-260.

[45]Santiago, T. (2014). La guerra humanitaria. Barcelona: Gedisa.

[46]Santos, d. B. (2015). Revueltas de indignación y otras conversas. La Paz: Proyecto Alice.

[48]Segura, M. (2006). Valores culturales de las wawas aymaras. Universidad Nacional Mayor de San Marcos. Lima: Universidad Nacional Mayor de San Marcos. Recuperado el 10 de noviembre de 2017, de http://cybertesis.unmsm.edu.pe/handle/cybertesis/2343

[49]Sharma, S. y. (2015). Selt-esteem and colective selfesteen among adolescents. Psychological Thought, 105-113.

[50]Surco, C. (2017). Gestión municipal. Puno: Sagitario.

[51]Tajfel, H. (1982). Social psychology of intergroup relations. Annual review of psychology, 1-39.

[52]Torres, D. (1967). Arte de la lengua aymara (Actualización de Mario Franco Inojosa). Lima: LYRSA.

[53]UNICEF. (2004). Igualdad con dignidad. Panamá: Fondo de las Naciones Unidas para la Infancia (UNICEF).

[54]Vygotski, L. S. (2000). Obras escogidas. Tomo III. Madrid: Visor.

[55]Weber, M. (1984). La ética del protestante y el espíritu del capitalismo. Madrid: Sarpe.

[56]Yapita, A. (2000). El rincón de las cabezas. La paz- Bolivia: ILCA. 